\title{
ESCREVER A PRÓPRIA VIDA: ASPECTOS ESTILÍSTICOS DO GÊNERO DIÁRIO PESSOAL
}

\section{JOCELMA BOTO SILVA}

Universidade Estadual do Sudoeste da Bahia

\section{MARCIA HELENA DE MELO PEREIRA}

Universidade Estadual do Sudoeste da Bahia

RESUMO A escrita de si é bastante reveladora: nela, emergem aspectos que revelam o que o autor almeja, mas também afloram aspectos que ele sequer cogitou para o registro de sua personalidade. De acordo com a teoria bakhtiniana, todo trabalho com a língua dá-se por meio de algum gênero discursivo. Portanto, o indivíduo que opta por escrever fatos da sua vida o faz a partir de algum gênero pertencente à esfera autobiográfica. Neste trabalho, nos propomos a investigar mais de perto o diário pessoal, cuja escrita é produzida diariamente ou em curtos intervalos de tempo. Para isso, investigamos dois diários de duas diaristas comuns, em busca de aspectos que evidenciam suas concepções sobre o gênero. Teoricamente, embasamo-nos na concepção de gênero discursivo, postulada por Bakhtin (1997), e nas investigações do pesquisador francês Philippe Lejeune (2014) acerca de autobiografias de pessoas comuns. Nossas investigações mostraram que a composição escrita desses diários se distingue, em vários aspectos, desde a concepção formal e estrutural do gênero até a função que ele representa para as escreventes. 0 gênero mostrou-se bastante flexivel, permitindo que as diaristas imprimissem nele seus estilos individuais.

Palavras-chave: Diário pessoal. Estilo. Gênero discursivo.

TO WRITE YOUR OWN LIFE: STYLISTIC ASPECTS OF THE PERSONAL DIARY GENRE

The written about yourself is quite revealing: on it, emerge aspect that reveal what the author craves, but also touch upon aspects that he had not even considered for the record of his personality. According to Bakhtin theory, all work with the language takes place through some discursive genre. Therefore, the individual who chooses to write facts of his life does it by using a genre belonging to the auto- 
biographical sphere. In this paper, we propose to investigate more closely the personal diary, of which's writing is produced daily or in short intervals of time. For that, we investigated two diaries from two ordinary writers, in search of aspects that show their conceptions of the genre. Theoretically, we rely on the conception of discourse genre postulated by Bakhtin (1997) and the investigations of the French researcher Philippe Lejeune (2014) about autobiographies of ordinary people. Our investigations have shown that the written composition of these diaries is distinguished in many aspects, since formal and structural design of the genre until the function that it represents for the writers. The genre was very flexible, allowing the writers to imprint their individual styles.

Keywords: Personal diary. Style. Discoursive Genre.

\section{RESUMEN}

\section{ESCRIBIR LA PROPIA VIDA: ASPECTOS ESTILÍSTICOS DEL GÉNERO DIARIO PERSONAL}

La escritura sobre ti mismo es muy reveladora: en ella, emergen aspectos que revelan lo que pretende el autor, pero también afloran aspectos que él incluso no había considerado para el registro de su personalidad. Según la teoría Bakhtiniana, todo el trabajo con el lenguaje se produce a través de un género discursivo. Por lo tanto, el individuo que elige escribir hechos de su vida lo hace a partir de algún género perteneciente a la esfera autobiográfica. En este trabajo nos proponemos investigar más de cerca el diario personal, cuya escritura se produce todos los días o en intervalos cortos de tiempo. Para ello, hemos investigado dos diarios de dos escritoras comunes, en la búsqueda de aspectos que evidencian sus concepciones sobre el género. Teóricamente, nos basamos en la concepción del género de discurso postulada por Bakhtin (1997) y en las investigaciones del investigador francés Philippe Lejeune (2014) sobre autobiografias de personas comunes. Nuestras investigaciones han demostrado que la composición de la escritura de estos diarios se distingue en varios aspectos, desde la concepción formal y estructural del género, hasta la función que representa para las escritoras. El género se mostró muy flexible, permitiendo que las escritoras de diarios imprimiesen en ellos sus estilos individuales.

Palabras clave: Diario personal. Estilo. Género discursivo. 


\section{Introdução}

Para que serve um diário? Qual a razão para mantê-lo? Essas respostas são variáveis e dependem muito da razão pela qual o indivíduo foi induzido a escrever sobre os fatos da sua vida: por curiosidade, pelo desejo de expressão, pela vontade de se conhecer, de marcar sua existência, por imitação, ou, simplesmente, por nenhuma razão. Uma vez iniciado, o diário assume diversas funções para o autor, deixando de ser simplesmente uma vida listada no papel para, inclusive, tornar-se um gênero discursivo complexo, recheado de particularidades. Gênero este que ainda não foi totalmente desvendado.

No senso comum, o diário costuma ser visto como uma atividade secreta, passageira ou durável, irregular, antiga, comum e corriqueira: qualquer um pode ter um diário. Qualquer pessoa pode iniciá-lo sem aviso prévio; pode retomar a sua prática após anos; pode encerrá-la a qualquer instante. A única coisa que não é tão comum é o compartilhamento dessa atividade. Do mesmo modo que as pessoas se sentem motivadas à produção do diário, sentem-se impelidas a mantê-lo no mais absoluto sigilo, salvo alguns casos pontuais: tratamento psicológico ou descaso para com o fato de que alguém possa ler o conteúdo do texto, mas estes são casos mais raros.

Devido a esse olhar empírico sobre as práticas do diário, durante muito tempo não se investigou o gênero a partir das manifestações cotidianas; ao contrário, as investigações estiveram, inicialmente, acopladas ao cânone literário, ou seja, tratavam-se de análises dos grandes diários de autoria de pessoas ilustres ou representativas, ou de textos fictícios que possuíam um teor literário. Consequentemente, ignorou-se o caráter mais simples do diário: o dia a dia, como sugere a própria palavra.
É preciso frisar que não estamos descaracterizando a relevância das grandes obras, apenas apontando que, antes de se tornar uma obra reconhecida nacional e mundialmente, o diário é construído no cotidiano, abarcando os fatos corriqueiros sobre os dias de determinado sujeito. É também do caráter comum e simples do diário que pode nascer uma grande obra literária.

Partindo desse pressuposto, observamos, neste artigo, diários pessoais escritos por duas jovens comuns, produzidos no seu dia a dia, sem fins de publicação. Buscamos, com essa investigação, apresentar algumas questões relacionadas ao gênero, tais como: a concepção de diário que as escreventes têm e o estilo de escrita das diaristas. Para isso, analisamos dois diários escritos por duas jovens a quem trataremos pelas iniciais $\mathrm{K} \mathrm{e} \mathrm{C}$.

K. S. L. M. (referenciada como K), nossa primeira escrevente a ser investigada, tem, atualmente, 25 anos e é estudante de Nutrição. Ela iniciou suas atividades de escrita intima durante a infância, assim que aprendeu a escrever e ganhou seu primeiro diário. A autora não preservou seus primeiros escritos, que foram destruídos por ela mesma, mas manteve sua atividade de escrever sobre si. A opção por guardar os diários remete ao ano de 2008, quando ela tinha entre 17 e 18 anos. Todos os cadernos produzidos após esse ano estão igualmente guardados. A autora nos contou, em uma entrevista posterior que fizemos com ela, que seu intuito, com essa escrita, é guardar uma memória de si para seus descendentes e que, apesar de não ter cogitado a ideia de publicar seus textos, não se incomodaria se alguém o fizesse.

$\mathrm{K}$ nos cedeu um de seus cadernos pessoais para realizarmos nossas investigações, corresponde aos relatos feitos nos anos de 2008, 2010, 2011 e início de 2012. Ela relata que sua decisão por escrever diários deixou de ser se- 
creta e que não pretende abandonar a atividade, por enquanto. Atualmente, a autora produz suas confidências em outros suportes, de modo que nossa investigação não influencia na sua composição diarística.

C. R. B. (referenciada como C), nossa segunda escrevente, tem hoje 31 anos e recentemente concluiu o Ensino Médio, por meio do Programa de Educação de Jovens e Adultos (EJA). Ela iniciou sua escrita em diários quando tinha 28 anos e vivenciava uma crise matrimonial. Até a presente data, a autora escreveu seu dia a dia apenas em dois cadernos e não se considera uma diarista muito fiel, já que se esquece de escrever diariamente. 0 caderno cedido para análise corresponde ao ano de 2013 e reconta as fases de uma crise matrimonial vivida pela autora e as mudanças de cidade que ela e a família enfrentaram.

Como veremos nas análises, K e C são sujeitos com concepções diferentes a respeito de seus próprios diários, por isso investigaremos cada produção, separadamente. Para empreendemos nossa análise, lemos os diários em busca de elementos que respondessem aos nossos questionamentos. Em outras palavras, através dessa leitura, buscamos elementos linguísticos e/ou discursivos que nos revelassem acerca desses sujeitos e da escrita deles e também do gênero em si. Separamos as partes que nos chamaram a atenção e as fotografamos para que pudéssemos ilustrar a discussão. Em algumas dessas imagens, inserimos destaques, por meio de círculos, com o objetivo de enfatizarmos algum detalhe importante para a pesquisa.

Por último, acrescentamos à pesquisa uma entrevista gravada em áudio e transcrita, com as próprias diaristas, questionando-as a respeito dos momentos de seu texto que recortamos para a análise, no intuito de que elas próprias comentassem sobre eles. Dessa for- ma, intercalaremos, na discussão que faremos, alguns trechos das falas das autoras que foram coletados durante essa entrevista.

\section{Referencial teórico}

Para embasarmos nossas investigações, partimos do conceito de gênero, discutido em Bakhtin (1997), e das noções sobre autobiografia apresentadas em Lejeune (2014).

\section{0 conceito de gênero}

Para Bakhtin (1997), o enunciado é o produto da língua, pois toda atividade de comunicação verbal se dá por meio dele. Nesse sentido, a noção de enunciado está ligada à proposta de dialogismo. Afinal, o enunciado é "o garantidor do espaço do outro na dinâmica discursiva e, por conseguinte, constitui-se do fluxo de múltiplas vozes que ecoam da alternância dos sujeitos do discurso nas situações de comunicação" (RIBEIRO, 2010, p. 56).

Todo enunciado (oral ou escrito) traz em si características peculiares às situações de comunicação, pois eles estão relacionados a alguma esfera/campo de atividade humana - jurídica, jornalística, religiosa etc. Essas esferas elaboram seus tipos relativamente estáveis de enunciados aos quais Bakhtin (1997) denominou gêneros do discurso. Os gêneros refletem as características e apontam as finalidades de cada esfera, a partir do conteúdo temático, do estilo e da construção composicional do enunciado.

É importante destacarmos que, embora os gêneros estejam relacionados a formas linguísticas, eles não são formas estanques, modelos que devem ser seguidos; ao contrário, eles estão sujeitos às transformações sociais, pois, apesar de obedecerem a uma estrutura, não têm uma composição fechada em si mesma. É por isso que Bakhtin os nomeia relativamente estáveis. 
O autor constatou que as esferas da atividade humana são múltiplas, fator que ocasiona a variedade dos gêneros e a impossibilidade de delimitá-los. Para o pesquisador, cada esfera engloba seu repertório de gêneros, que podem ser multiplicados, à medida que as esferas são ampliadas e ficam mais complexas. Este fenômeno pode ser exemplificado, hoje, com o advento das mídias digitais, que geram uma infinidade de outros gêneros, como e-mails, blogs, chats etc. Muitos desses novos gêneros surgiram sob velhas bases, conforme destacou Marcuschi (2003). O autor cita o e-mail como exemplo, que gera mensagens eletrônicas que têm as cartas e os bilhetes como seus antecessores.

Ao se propor a investigar os gêneros discursivos, Bakhtin (1997) observou que eles eram ilimitados. Para facilitar a reflexão sobre eles, dividiu-os em primários e secundários. Os primários aparecem em uma situação comunicativa mais simples, como um diálogo, e agrupam os gêneros do cotidiano. Já os secundários, surgem em situações comunicativas mais complexas, de ordem científica, sociopolítica, por exemplo, e, geralmente, são efetivados por meio da língua escrita.

\section{0 gênero diário pessoal}

O diário dá-se no calor do momento, no instante em que o diarista se vê entusiasmado a recontar os fatos mais interessantes de seu dia. Por meio dele, transcrevem-se pensamentos e sentimentos que são únicos a determinados momentos e ficam eternizados pela escrita: o registro permanece inquieto para reviver a memória. Cada palavra que foi escolhida para a escrita assume um papel importante na configuração do diário, que registra as sensações de momentos específicos.

Mas o diário é muito mais complexo que um "quarto de despejo" ou que um "icone de memória", como se costuma veicular no senso comum. Ele pode assumir várias funções e características que o singularizam diante dos demais gêneros da esfera autobiográfica. Essas particularidades dizem respeito à relação do diarista com seu texto. De acordo com Lejeune (2014), nessa relação, o diário pode assumir a função de conservar a memória, sobreviver, desabafar, conhecer-se, deliberar, resistir, pensar e escrever. 0 pesquisador apresentou essas sete funções, buscando situar as utilidades desse gênero.

Enquanto conservador da memória, o diário é "arquivo e ação 'disco rígido' e memória viva" (LEJEUNE, 2014, p. 302), de modo que o sujeito tem a possibilidade de guardar os fatos do dia e, quando desejar, acessá-los. Esses fatos escritos estarão intactos e funcionarão como um "rastro" atrás do indivíduo. Afinal, sua memória poderá ser acessada em um futuro breve ou distante, se o diarista assim o desejar.

O diarista ainda escreve para sobreviver, para que sua vida não caia no esquecimento. Ainda que não se tenha coragem para lê-lo ou deixá-lo ser lido "o diário é um apelo a uma leitura posterior: transmissão a algum alter ego perdido no futuro" (LEJEUNE, 2014, p. 303). O diário é um amigo com o qual se pode desabafar, um confidente que não julga ou critica, "é um espaço onde o eu escapa momentaneamente à pressão social, se refugia protegido em uma bolha onde pode se abrir sem risco, antes de voltar, mais leve, ao mundo real" (LEJEUNE, 2014, p. 303). Também é um espelho no qual projetamos a nossa imagem, sobre a qual, de maneira distanciada, podemos chegar a nos conhecer.

Esse gênero também ajuda a deliberar, pois ele acompanha a tomada de decisões no dia a dia do indivíduo, passando a ser "um dos instrumentos de ação" (LEJEUNE, 2014, p. 304) para o diarista, e não apenas um elemento passivo. 0 diário é resistente, é o apoio em to- 
dos os momentos, sejam eles bons ou ruins, é forte e aguenta as provações pelas quais o autor pode passar.

O diário também pode ser um espaço de criação, pois pode conter pensamentos e textos literários. Essa função talvez justifique os diários que são publicados devido ao cuidado artístico do autor com sua escrita. Sobretudo, o diário é mantido pelo prazer em escrever, pelo gosto da escrita, pelo jogo possivel na mistura dos gêneros, pela satisfação em escolher qualquer palavra sem ser censurado, pela magia de ver-se escrito, de ter a sua personalidade transformada em letras. Essas características confirmam o que aponta Lejeune (2014) ao salientar que "o diarista não tem a vaidade de se acreditar tornar escritor, mas encontra em seus escritos a doçura de existir nas palavras e a esperança de deixar um vestígio" (LEJEUNE, 2014, p. 306).

E como defini-lo, então? Tomamos uma definição que nos parece mais apropriada no momento e consideramos o diário como "uma série de vestígios datados" (LEJEUNE, 2014, p. 299). Compreendemos o vestígio no seu sentido original, como sinais, marcas que se deixa em algumas circunstâncias. O diário é, portanto, um conjunto de sinais que o indivíduo deixa sobre si em textos que escreve com essa finalidade. Notemos que essa primeira definição não aborda a destinação, a forma e o conteúdo do diário, pois esses itens são variáveis. No entanto, existe um consenso quanto à formatação do diário: a fragmentação e a repetição. A partir disso, com base em Lejeune, situamos o gênero como uma série de vestígios fragmentados e repetitivos.

Essa série de vestígios não precisa, rigorosamente, obedecer a uma sequência ininterrupta. Afinal, o diarista pode escrever os fatos de dois ou mais dias em uma única entrada,

1 Philippe Lejeune (2014) nomeia por "entrada" ou "registro" toda narração que está escrita sob uma mesma data. Nessa pesquisa, tomaremos a nomenclatura pode deixar a prática e retomá-la mais tarde e, ainda desse modo, não cair em outro gênero, como a autobiografia, por exemplo.

Por ser uma escrita que visa marcar o tempo, a base do diário é a datação. Essa marca é fundamental para caracterizar o gênero, tanto que a sua ausência pode implicar a ocorrência de outro gênero da esfera autobiográfica como as memórias, por exemplo (LEJEUNE, 2014). Ainda que a data não esteja, a rigor, especificada no alto da página, ela deve ser indicada, mesmo que seja no decorrer do texto. Esse tipo de indicação tem o propósito de marcar a data de ocorrência de determinado fato.

\section{Diários de K e de C: a análise}

Como já enfatizamos, na introdução, as duas produções diarísticas que vamos analisar apresentam distinções e, por esse motivo, vamos analisá-las individualmente. Iniciaremos nossa investigação pelo diário de $\mathrm{K}$ e, em seguida, observaremos as análises no diário de C.

\section{O diário de $K$}

Logo nas primeiras páginas, notamos a construção de uma escrita de diário com um estilo muito singular, não tão padronizado, como diria Bakhtin (1997). A confecção do diário não apresenta a estrutura padrão em que normalmente se encontra a data no alto da página, seguida pelo vocativo, a narração e a despedida. Nossa autora parece não se engessar nessa proposta do gênero, ao contrário, apresenta uma configuração que valoriza a narrativa em detrimento da forma, de modo que, à primeira vista, não se identifica um diário, nota-se, pois, o gênero, à medida que a narração acontece. Vamos observar a figura 1, a seguir:

sugerida pelo autor para nos dirigirmos aos textos escritos pelas nossas diaristas. 
Figura 1 - Características da estrutura formal e ilustrativa do diário escrito por $\mathrm{K}$

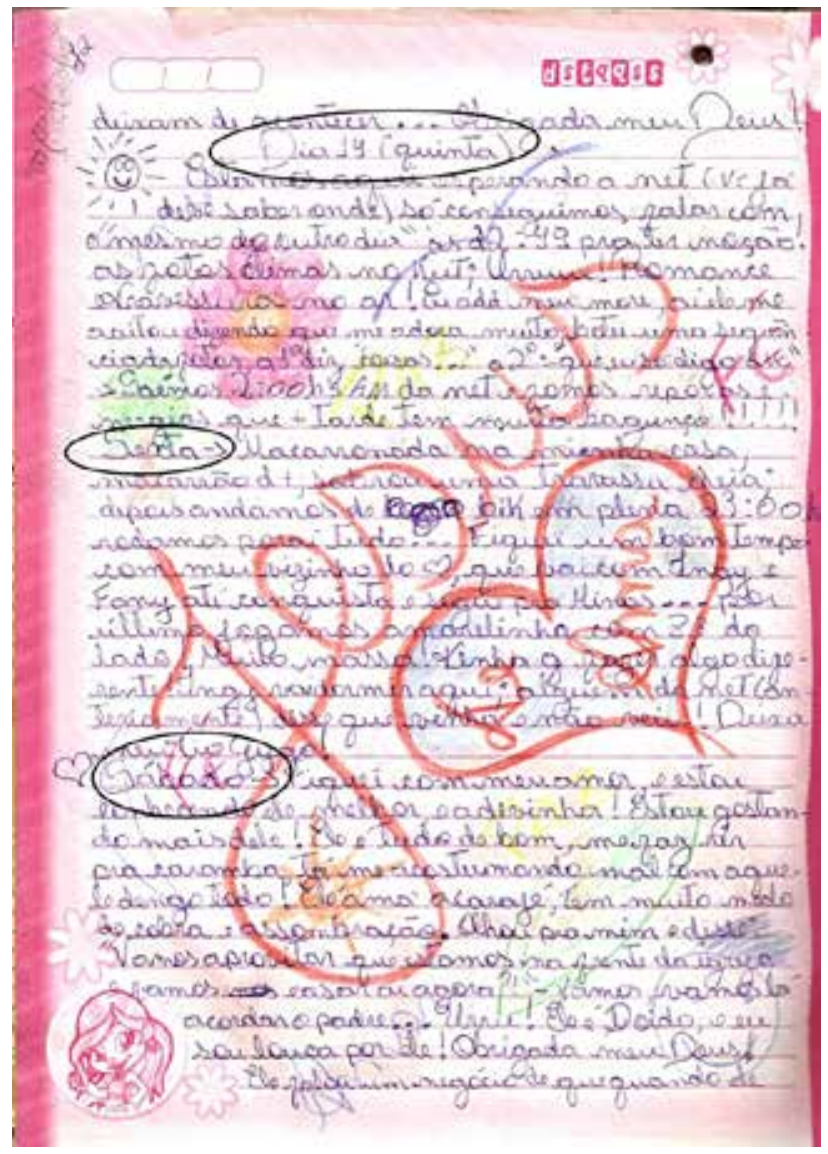

Fonte: banco de dados das autoras.

Podemos observar que, em uma mesma página, estão dispostas as narrações correspondentes a três dias distintos: quinta, sexta e sábado, como nós destacamos na figura. Notamos que a indicação dos dias correspondentes aos relatos ocorre de maneira muito sutil, de tal modo que se percebe a mudança dos dias no decorrer da leitura ou com um olhar mais cauteloso. Além disso, é importante destacar que não há qualquer evidência do mês ou do ano em cada relato; é preciso que o leitor esteja atento às narrações, pois a autora não se prende a estas questões, como geralmente se observa na escrita de diários. Pelo contrário, para essa composição escrita, parece que a autora renunciou a alguns princípios comumente aplicados a diários e criou os seus próprios, em que a data pode ser indicada somente pelos dias da semana, se ela assim o desejar; o ideal de que "cada narração deve comportar uma página diferente" não se aplica nessa escrita; também não há necessidade de despedida ou introdução da narração.

Essa opção de estrutura formal não modifica a função do gênero, que continua a contemplar o relato diário dos fatos vividos por alguém. No entanto, indica um estilo do autor sobre o gênero. Sobre essa questão, Possenti (2001) considera que o estilo é da ordem da escolha, que é, por sua vez, compreendida como "efeito de uma multiplicidade de alternativas [...] diante das quais escolher não é um ato de liberdade, mas o efeito de uma inscrição" (POSSENTI, 2001, p. 17), ou seja, é consequência da exigência enunciativa.

A emergência de tal estilo composicional parece proposital e consciente, pois a autora conta que houve uma mudança na estrutura dos seus primeiros diários até os atuais. Segundo ela, os primeiros cadernos obedeciam à forma comum ao diário, mas com o tempo, essa questão foi abandonada com o seguinte argumento, colhido na entrevista posterior que fizemos com K: "eu sempre tratei o diário como um amiguinho que não fala e não te responde, aí eu já começava a falar com ele como fala com um amigo mesmo [...] eu já ia falando aconteceu isso, aconteceu aquilo, não gostei, gostei [...] eu achava 'meu querido diário' muito estranho", explica ela. Nota-se, pois, uma configuração do gênero desprendida da forma tradicional, em favor da sua função, que é registrar a própria vida. Conforme explica Lejeune (2014), "cada um inventa seu próprio caminho nesse gênero do qual existem talvez modelos, mas nenhuma regra" (LEJEUNE, 2014, p. 299). Ou seja, a estrutura não diz muita coisa ao diarista, mas, sim, sua funcionalidade.

Ainda sobre o estilo dessa autora, há vários outros momentos em que ele aparece. Dessa vez, no destaque em cores e na inserção de desenhos sobre o texto escrito. Vamos observar mais uma imagem, a figura 2: 
Figura 2 - Aspectos estilísticos na escrita de $\mathrm{K}$

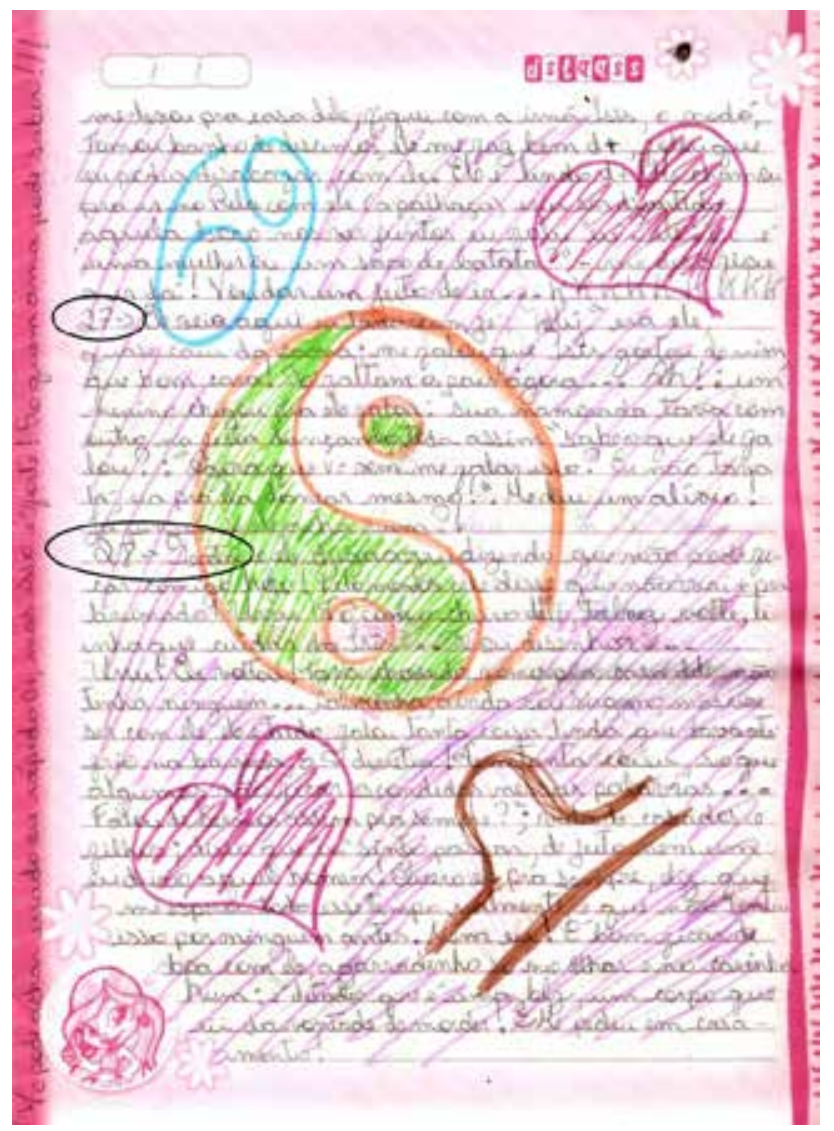

Fonte: banco de dados das autoras.

Notemos que, nesse exemplo, a indicação das datas também é sutil. A autora escreve os relatos do dia 27 e 28 , como nós destacamos, em círculo. Além disso, podemos notar que há a presença de desenhos e símbolos sobre a narrativa. Este fator também caracteriza a escrita dessa autora. Durante a entrevista, K conta que o ato de desenhar por cima da escrita acontecia como forma de deixá-la mais divertida, "mais legal"2 e que a seleção do desenho estava relacionada com o seu estado emocional: "se eu estava feliz, colocava desenho feliz, se estava triste, colocava desenho triste". Além disso, a autora nos contou que sempre gostou muito de símbolos e que os reproduzia quando se sentia cansada de desenhar corações, a fim de "colorir" a narrativa.

Ainda sobre esse hábito de ilustrar seus

2 Os trechos destacados entre aspas, neste parágrafo, são trechos da entrevista em áudio realizada com a autora K. diários, podemos discutir outros aspectos. Observemos a próxima imagem (figura 3):

Figura 3 - Inserção de elementos avulsos do diário escrito por $\mathrm{K}$

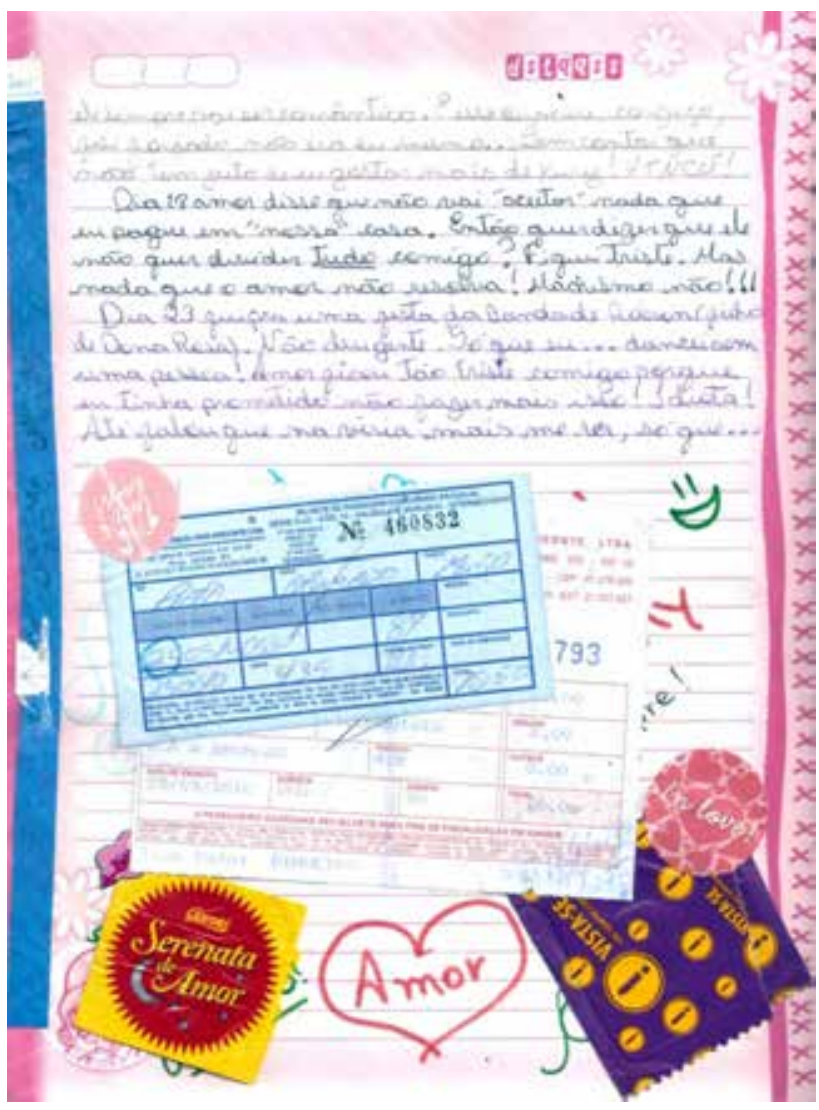

Fonte: banco de dados das autoras

Notamos que foram inseridos alguns elementos na página: dois tickets de passagens de ônibus, uma pulseira disponibilizada em eventos, um papel de bombom, uma embalagem de preservativo, um adesivo escrito "In Love" e os desenhos produzidos pela autora. Nessa página, tem-se o resquício da narração de um dia intitulado "domingo", que discorre rapidamente sobre a visita de alguns amigos e uma conversa fria que teve com o namorado, por telefone. Tem-se, na íntegra, a narração do dia 18, que foca uma impressão de atitude machista do namorado, e a narração do dia 23, que discorre sobre um desentendimento entre ela e o companheiro, devido ao fato de $\mathrm{K}$ ter ido a uma festa e ter dançado com outro rapaz. 
Como citado anteriormente, $\mathrm{K}$ não evidencia o mês da narrativa e não segue uma estrutura padrão para a formatação do gênero. No entanto, o que nos chamou a atenção foi o fato de que, em nenhuma das narrações citadas, tem-se a menção ou a justificativa da presença dos elementos ilustrativos que compõem esta página. De acordo com a autora, é possivel que a pulseira esteja relacionada à festa mencionada, no entanto, ao perguntarmos a ela a esse respeito, disse-nos que não se lembrava da presença dos outros elementos ilustrativos, nessa página. Nesse sentido, gostaríamos de mostrar, ainda, um último exemplo desse seu estilo, conforme a figura 4:

Figura 4 - Inserção de elementos memorialísticos do diário escrito por $\mathrm{K}$

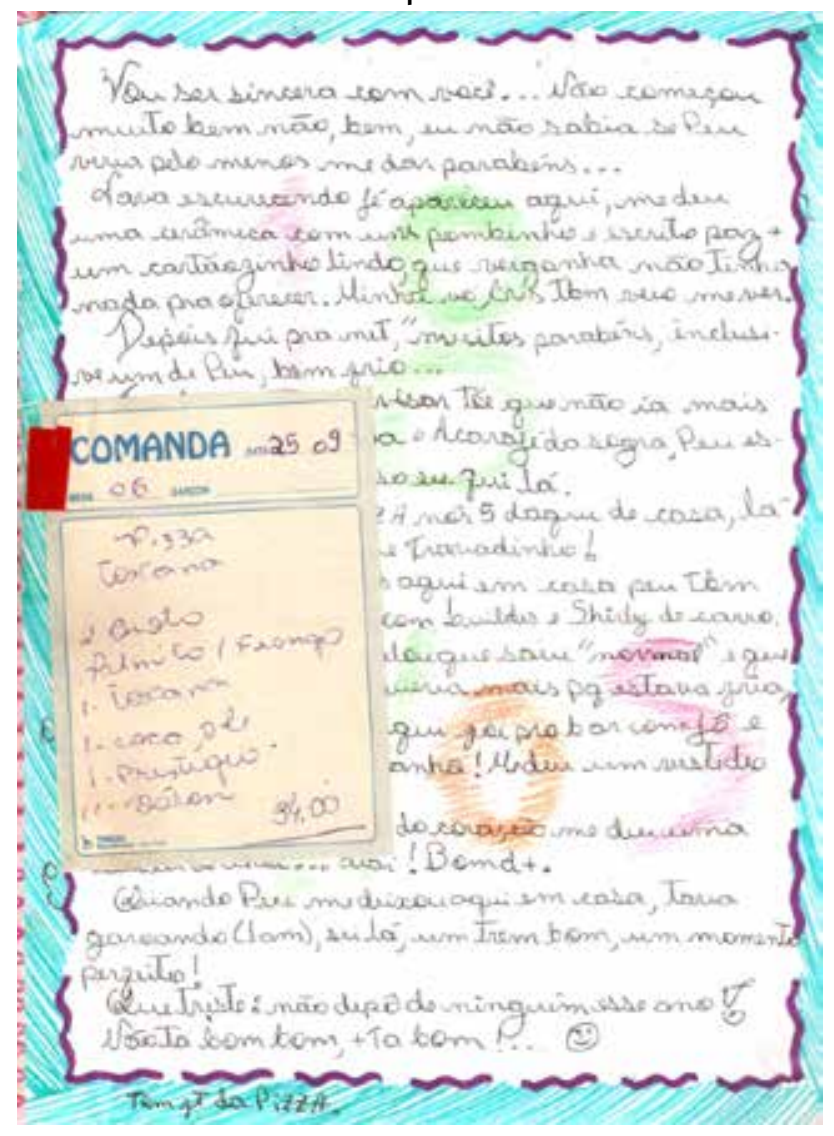

Fonte: banco de dados das autoras.

Nessa página, K escreve sobre seu aniversário de 18 anos, fato destacado por meio de lápis coloridos sobre o texto. A autora reconta os fatos desse dia e menciona a ida a uma pizzaria, em comemoração à data. Diferentemente do exemplo anterior, a comanda inserida na página tem relação com o fato descrito, pois aponta o pedido realizado na pizzaria. Além disso, a data disposta na comanda confere com a data de aniversário da autora. Ou seja, nesse caso, o elemento aparece como recurso de memória, ou, nas palavras de K: "o comprovante de que aquilo aconteceu mesmo". Por meio desses exemplos, podemos destacar que as ilustrações e anexos que compõem a escrita dessa autora tanto podem ter sido inseridos de forma aleatória como podem ter sido inseridos para relembrar algo que tenha acontecido na data em questão. Ou seja, temos as duas possibilidades e só saberemos se as ilustrações têm relação com as entradas a partir da leitura do conteúdo escrito.

Ainda sobre a imagem anterior, podemos notar que a folha sobre a qual a narrativa foi realizada não pertence ao conjunto de folhas desse caderno. Foi algo confeccionado à parte e inserido posteriormente. Ocorrências como esta fazem parte dos anexos que $K$ costuma inserir em seus diários, prática então adotada e que faz parte do seu estilo. Observemos outros exemplos nessa direção (figuras 5 e 6):

Nessas imagens, detectamos que existem páginas inteiras anexadas à narrativa. No primeiro caso, constam as reflexões da autora sobre um fato e um bilhete do namorado. No segundo, temos um relato em uma das folhas, e uma citação de um texto de Carlos Drummond de Andrade, na outra. Ao contrário do exemplo anterior, essas páginas não estão abertas e fáceis de serem lidas, já que estão dobradas e exigem do leitor o cuidado de abri-las para conhecer o conteúdo. Sobre esse fato, a autora nos contou, na entrevista, que muitas vezes produzia os seus relatos em outros cadernos e folhas soltas e os inseria no diário, posteriormente, porque "não estava com o cader- 
no na hora e queria escrever, tipo: não tinha tempo em casa, aí na faculdade a aula tava muito chata, eu pegava uma folhinha qualquer e começava a escrever [...] e anexava mais ou menos na data no caderno", diz K. Ocorrências como essa seriam da ordem da descontinui- dade? Acreditamos que não, pois não há uma paixão pelas "folhas soltas", como destaca Lejeune (2014). A inserção dos anexos no caderno atesta "a promessa mínima de unidade" (LEJEUNE, 2014, p. 338), configurando, assim, a continuidade no gênero.

Figuras 5 e 6 - Inserção de anexo no diário escrito por K

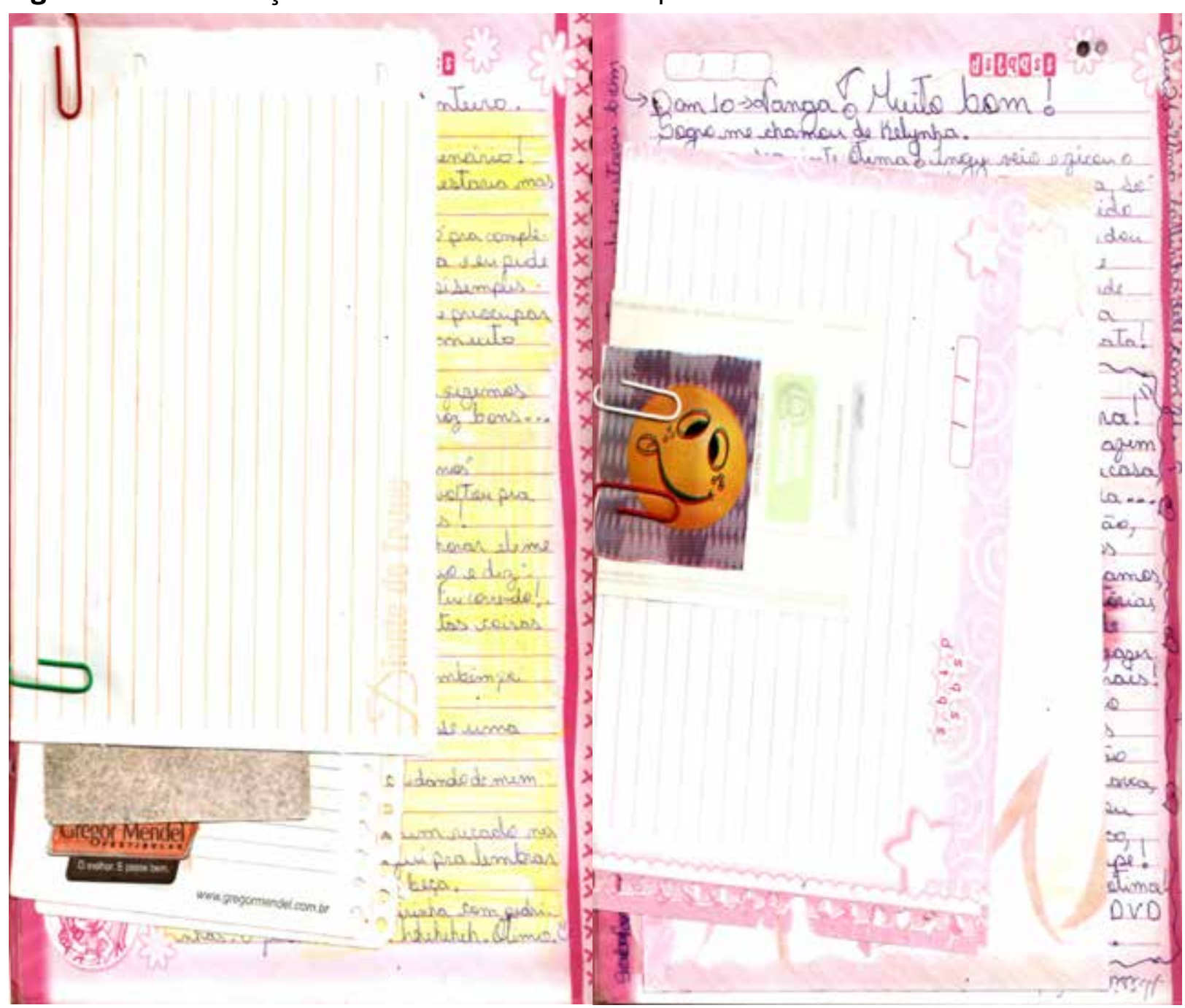

Fonte: banco de dados das autoras.

\section{$\mathbf{O}$ diário de $\mathrm{C}$}

Conforme já dissemos, $\mathrm{C}$ nos cedeu apenas um diário para a análise. Ele foi escrito em um caderno pequeno, de capa dura, de cor azul, com 96 folhas. Antes de tornar-se diário, o caderno era utilizado como uma caderneta de anotações de informações escolares do filho, contendo os horários de aula dele, recados dos professores e dos diretores da escola. 0 uso do caderno para esse fim limitou-se ao conjunto de seis páginas preenchidas na frente e no verso. Ainda antes de ser um diário, o caderno foi reaproveitado para anotações de receitas culinárias, como podemos observar na figura seguinte (figura 7): 
Figura 7 - Usos iniciais do suporte: caderneta de anotações escolares e livro de receitas

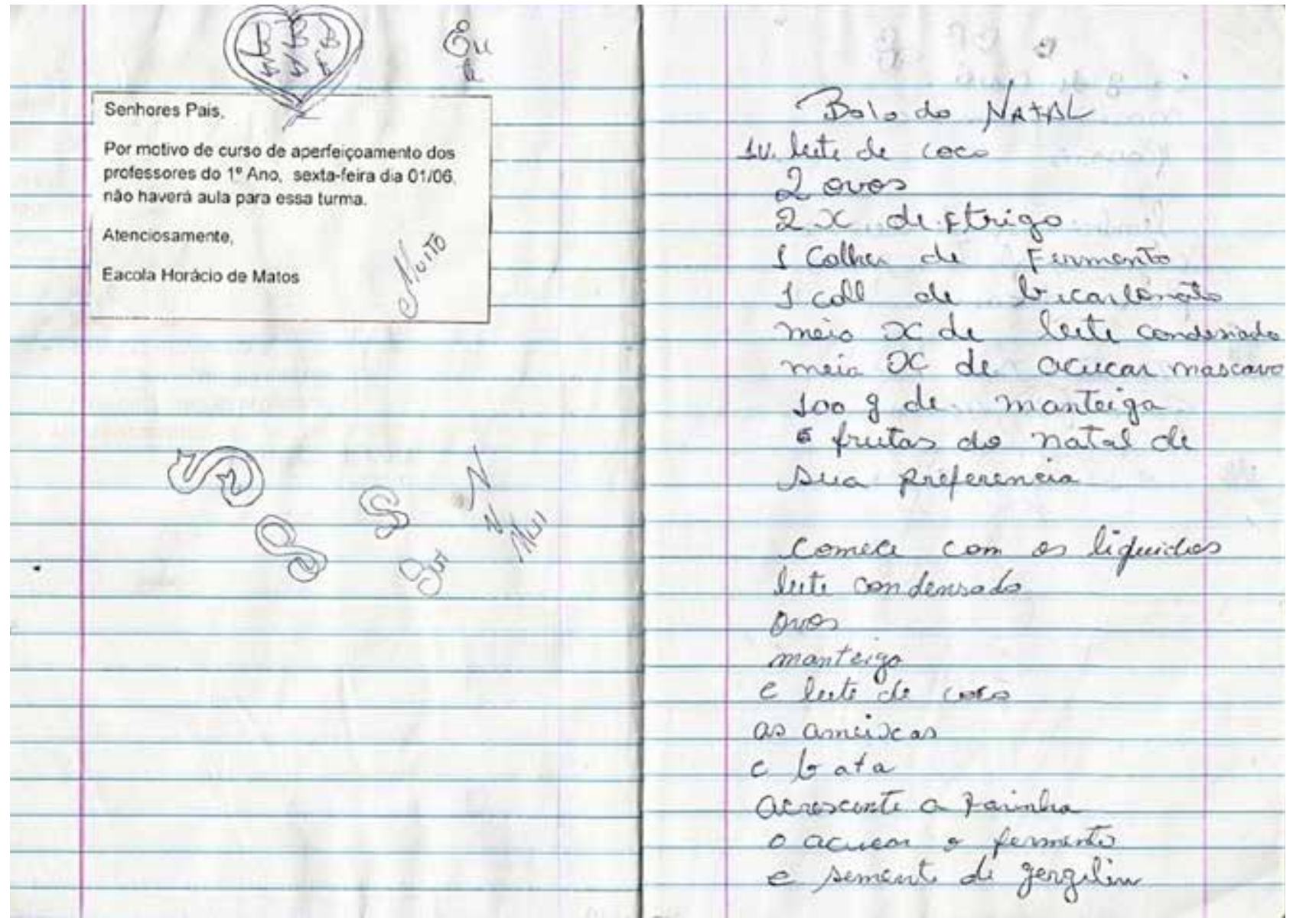

Fonte: Banco de dados das autoras.

É somente após esses usos que o caderno vem a ser seu Diário. Na entrevista posterior que fizemos com $C$, ela nos disse que reaproveitou o material do filho por acreditar que, devido à sua idade (28 anos, na época), "não combina ir até a loja para comprar um diário". O fato do caderno ter sido reaproveitado não incomodou a autora, pois, como ela mesma nos relatou, não acreditava que alguém fosse conhecer seu hábito de escrita íntima e, portanto, proferir qualquer observação sobre ele, uma vez que "ela nem comprou um caderno novo!" Essa ocorrência comprova que a escrita de diários se dá dissociada de avaliações externas, reafirmando, assim, o caráter intimista do gênero.

Ao decidir escrever os fatos de sua vida nesse caderno, $C$ realiza uma divisão nele, se- parando o conteúdo existente anteriormente dos relatos que começa a fazer, conforme ilustra a próxima figura (figura 8):

Observemos que essa folha dobrada em forma de triângulo é o marco, a sinalização para o interlocutor de que é a partir desse ponto que o diário foi iniciado. A autora relatou, na entrevista, que a divisão indica onde, de fato, o diário é iniciado e que ela serviu como marcação de página porque "ficava mais fácil para eu abrir e começar a escrever". Ao observarmos mais atentamente a figura acima, notamos que, da mesma forma que o diário de $\mathrm{K}$, investigado anteriormente, temos uma nomeação: Meu Diário. Essa nomeação é um pouco mais tradicional que a nomeação feita por $\mathrm{K}$, que intitulou seu diário de Diário de uma paixão. De qualquer forma, ambas situam o leitor. 
Figura 8 - Divisão do caderno para o início da escrita diarística; primeira folha escrita do diário de C

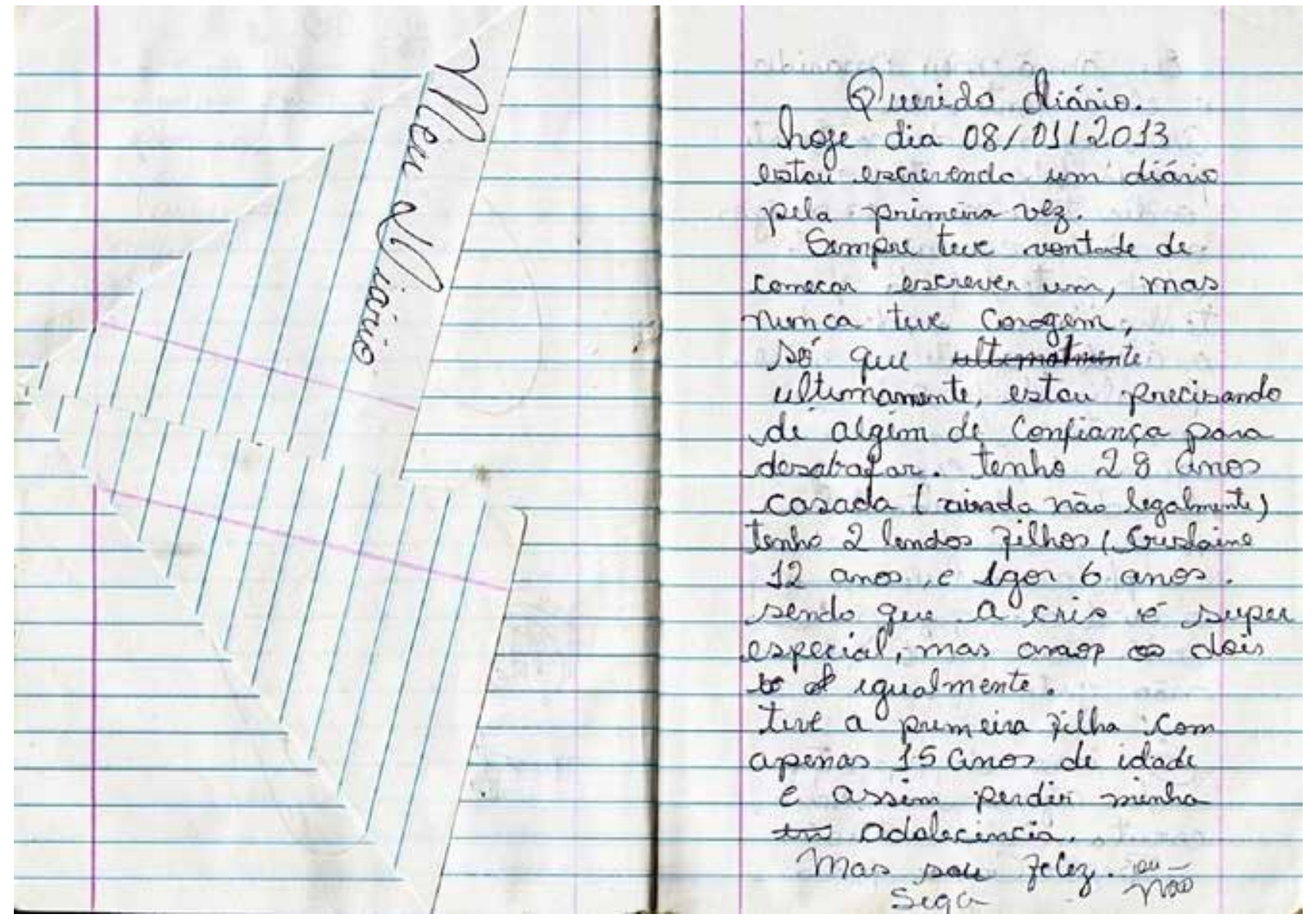

Fonte: banco de dados das autoras.

O diário foi iniciado no dia 08 de janeiro de 2013. Nesse primeiro momento, a autora propõe ao interlocutor uma breve apresentação de si e das pessoas que a rodeiam. Diz que decidiu escrever por buscar, no caderno, uma forma de desabafar. Informa que é casada e que tem dois filhos. Enfim, faz um breve apanhado sobre quem é, o que faz e quem está envolvido na sua vida.

Nessa mesma data, em outra folha, a autora produz seu primeiro relato diário. Vejamos seu conteúdo, conforme nos mostra a figura 9:

A partir dessa entrada, começamos a conhecer os fatos vivenciados por essa autora. Nesse relato, ela conta que sentia dor de dente e que um irmão que há muito não via estava presente para passar o Natal com a família e que acreditava que ele estava triste. A autora encerra a entrada da seguinte maneira: "Ó, Deus, proteja toda minha família. Meus filhos.
Figura 9 - Primeiro relato do diário de C

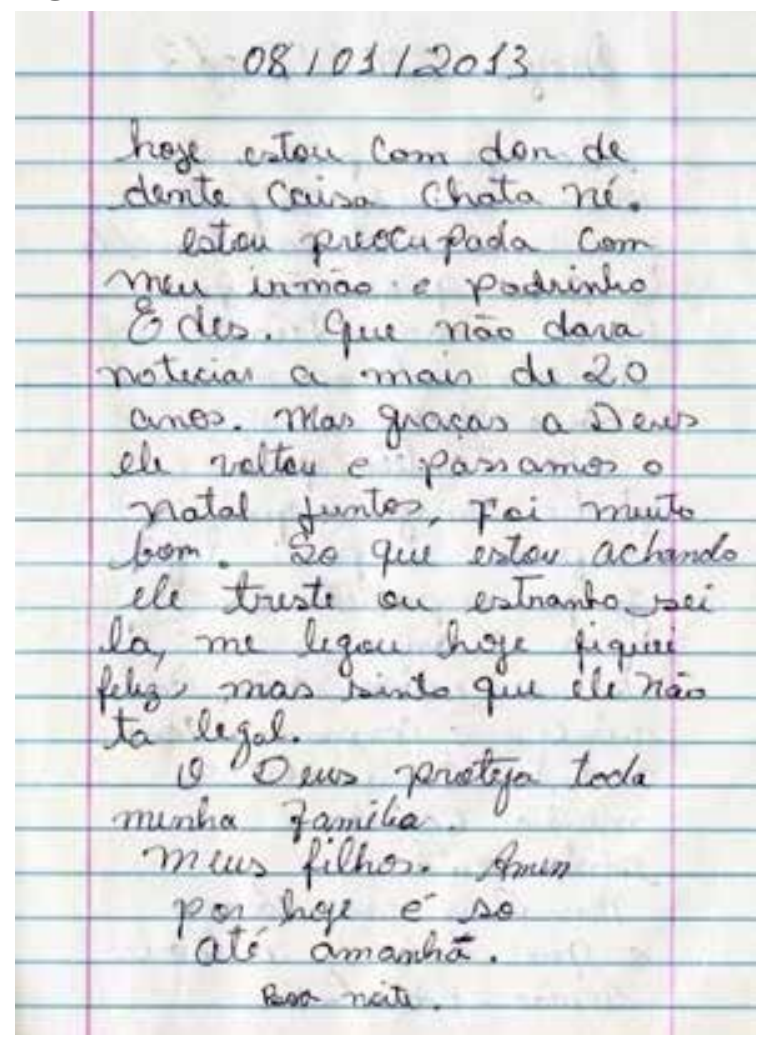

Fonte: banco de dados das autoras. 
Amém. Por hoje é só, até amanhã. Boa noite". Desde essa primeira narração, observamos algo bastante peculiar ao estilo de escrita de C: a recorrência religiosa nas narrativas. Nesse caso, em específico, percebemos que sua nar- rativa atua com um tom de oração, de prece. Essas ocorrências caracterizam as narrativas da autora e fazem com que percebamos uma de suas faces: o religioso. Vejamos outros exemplos dessa ocorrência (figuras 10 e 11):

Figuras 10 e 11 - Aspectos da escrita religiosa no diário de $C$

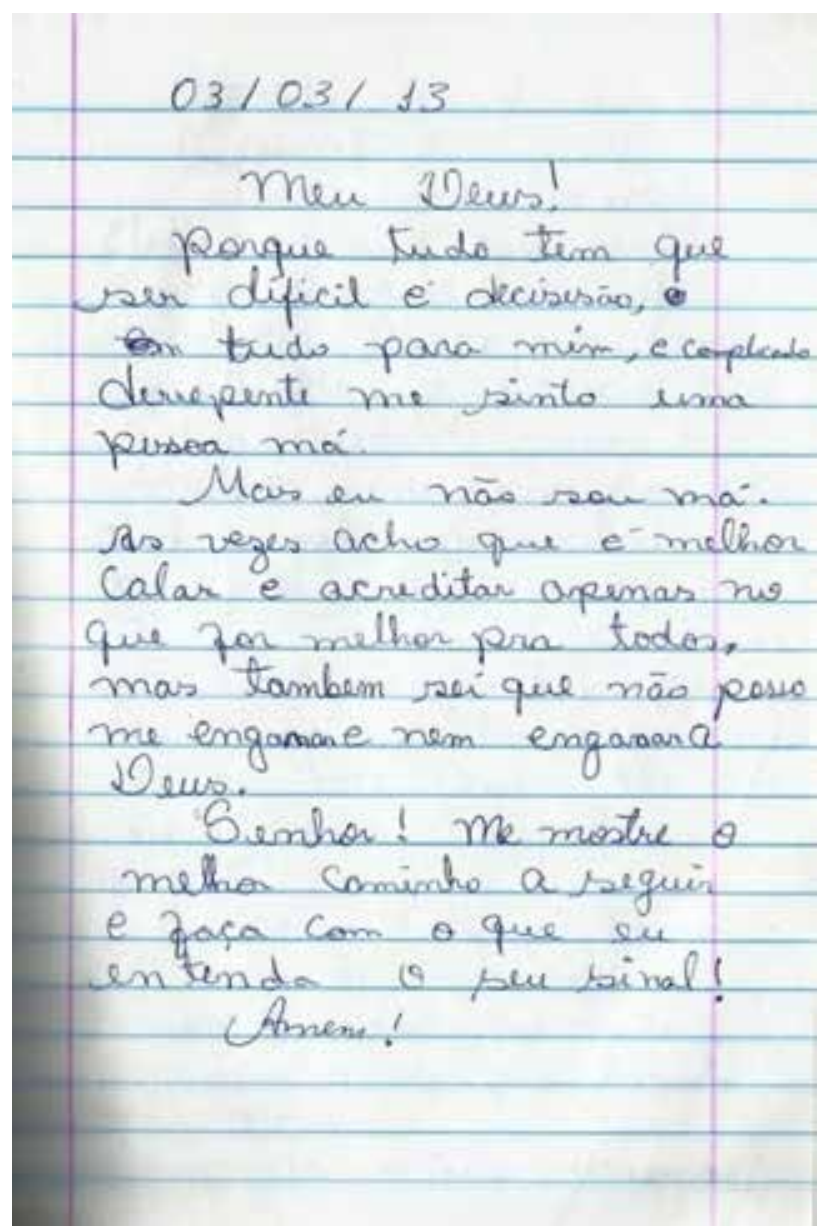

Fonte: Banco de dados das autoras.

Nestas duas imagens, a escrita da autora é amplamente reflexiva. Apesar de ser uma entrada em um diário pessoal e de, visualmente, respeitar-se a estrutura formal do gênero, linguisticamente falando, temos ocorrências de preces e reflexões proferidas a partir dos fatos vivenciados pela autora. Na primeira imagem, $C$ reflete sobre a condição de ser ou não ser uma má pessoa. Ela inicia a narrativa utilizando o vocativo "Meu Deus" e constrói todo o texto a partir desse viés. No encerramento, escreve a seguinte prece: "Senhor, me mostre o melhor caminho a seguir e faça com que eu entenda

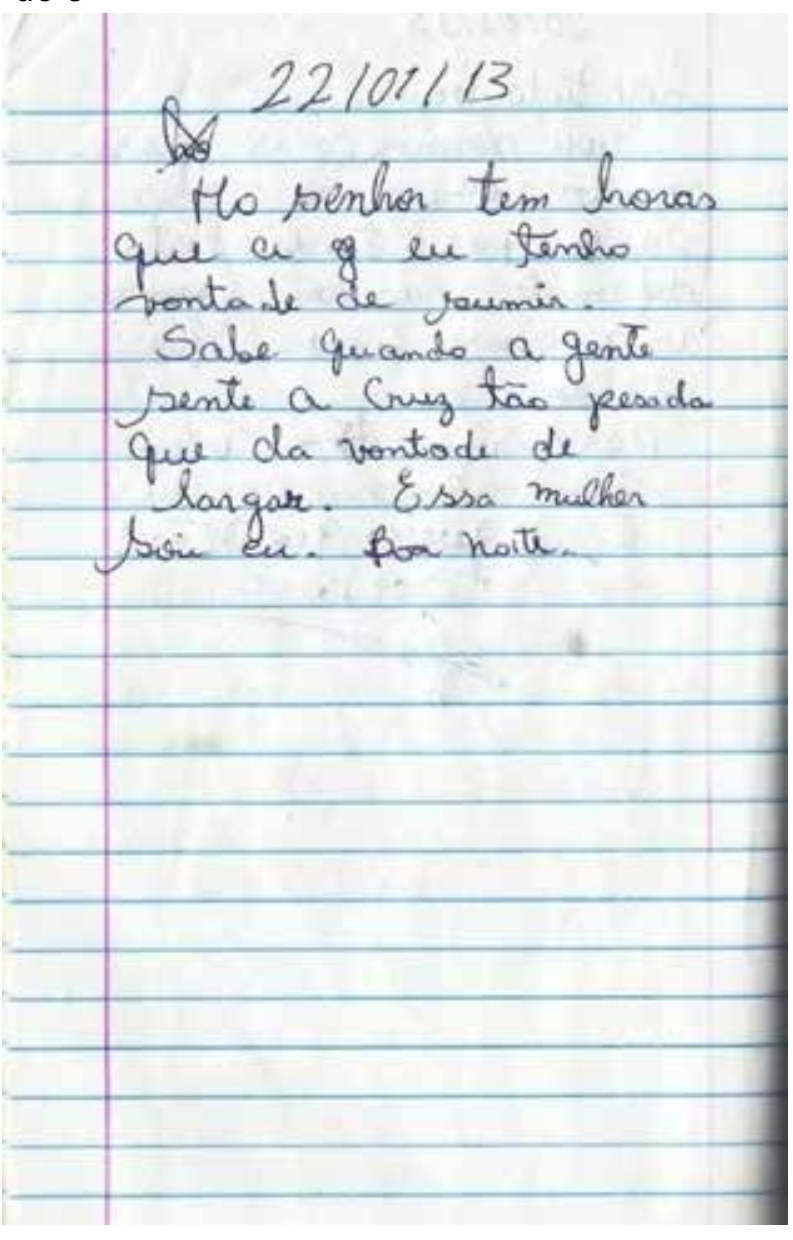

o seu sinal! Amém!". Esses indícios fazem com que a produção textual dessa data assuma o papel de diálogo entre ela e o Divino, devido ao tom piedoso e religioso que ela dá ao texto.

$\mathrm{Na}$ segunda imagem, em um texto menor, C recorre também ao interlocutor divino, "Senhor", para recontar a sua vontade de sumir. Apesar de não conter uma prece, nesse caso, temos, além do vocativo, mais uma menção fortemente religiosa: a palavra "cruz", como podemos notar na frase seguinte: "Sabe quando a gente sente a cruz tão pesada que dá vontade de largar. Essa mulher sou eu". 
Tendo como base esses exemplos, notamos que a escrita dessa autora assume um papel reflexivo sobre os fatos cotidianos vivenciados por ela. Apesar de não estar evidente quais foram as situações que a levaram a produzir essas escritas mais reflexivas, o que prevalece, em ambas, é o aspecto religioso.

A partir desses exemplos, poderíamos classificar o diário de $\mathrm{C}$ como um diário espiritual? Precisamos tomar a questão com cautela. Se pouco se tem estudado sobre diários escritos por pessoas comuns, menos ainda se tem estudado sobre os diários espirituais. Philippe Lejeune propôs-se, ainda que rapidamente, a falar sobre esse outro gênero da esfera autobiográfica e constatou que o objetivo dele é fazer com o que indivíduo "abandone-se" para alcançar a Deus (LEJEUNE, 2004), ou seja, com que ele busque a pureza da alma, sua salvação.

$\mathrm{Na}$ sua origem, esse tipo de escrita era orientado para os seminaristas, noviças e outros "profissionais" católicos, atuando como uma "direction de conscience", 3 como constatou o próprio Lejeune (2004). O autor ainda considera que "le journal spirituel a-t-il deux faces: l'une 'morale ou psycologique', ou l'attention à soi risque de déparer vers la complaisance; l'autre 'mystique' ou l'attention a Dieu entraîne l'individu débarassé de lui-même vers lês sommets" ${ }^{4}$ (LEJEUNE, 2004, p. 8). Desse modo, temos, de um lado, o diário espiritual, produzido por obediência ou submissão e, de outro, o diário espiritual, produzido de acordo com sua função: a salvação da alma.

Tendo em vista essa função primordial do diário espiritual, não acreditamos ser conveniente classificar o diário de $\mathrm{C}$ como tal, por duas razões aparentes: a primeira, porque não

3 Direção de consciência (tradução nossa).

4 "O Diário espiritual tem duas faces: uma 'moral ou psicológica', em que a atenção para si corre o risco de cair na complacência; a outra 'mística', em que a atenção para Deus leva o indivíduo a abandonar a si mesmo por completo". (LEJEUNE, 2004, p. 8, tradução nossa) se trata da escrita de uma noviça e, sim, de uma mulher que não assumiu qualquer função religiosa perante a sociedade, como constatamos no decorrer da sua escrita. A segunda razão é que não há abandono total de si em busca da pureza da alma. Pelo contrário, os escritos voltados a Deus acontecem em número significativo, mas o que marca a narrativa são as angústias vivenciadas pela autora. o que temos, nesse diário, são trechos religiosos aos quais preferimos denominar por "marcas de um sujeito", um sujeito afetado pela fé, pela crença no divino, ou seja, tomamos a questão da religiosidade como característica do sujeito $C$.

Além desse "eu" religioso, outro aspecto nos chamou a atenção no diário de C: a inserção de poemas autorais. Vejamos as figuras a seguir, que trazem dois poemas escritos pela autora.

Figuras 12 - Ocorrências de poemas no diário de C

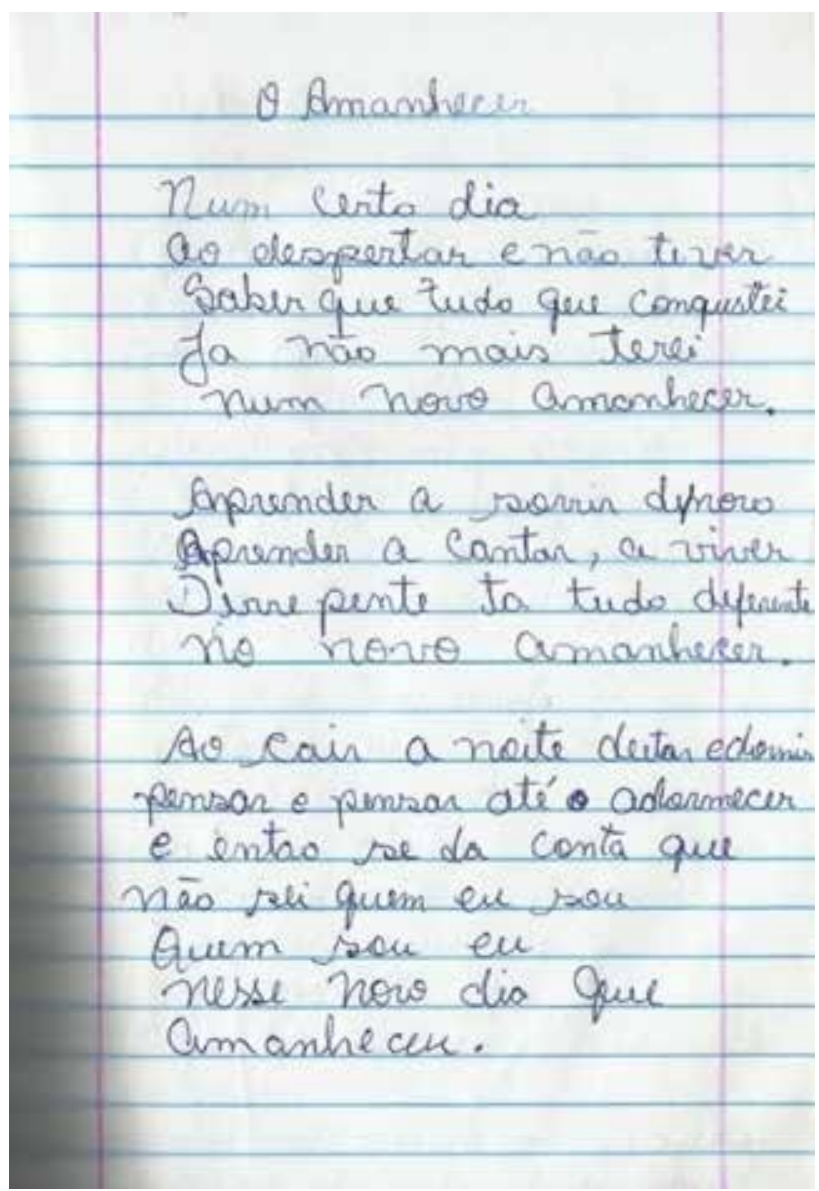

Fonte: banco de dados das autoras. 
Figuras 13 - Ocorrências de poemas no diário de C

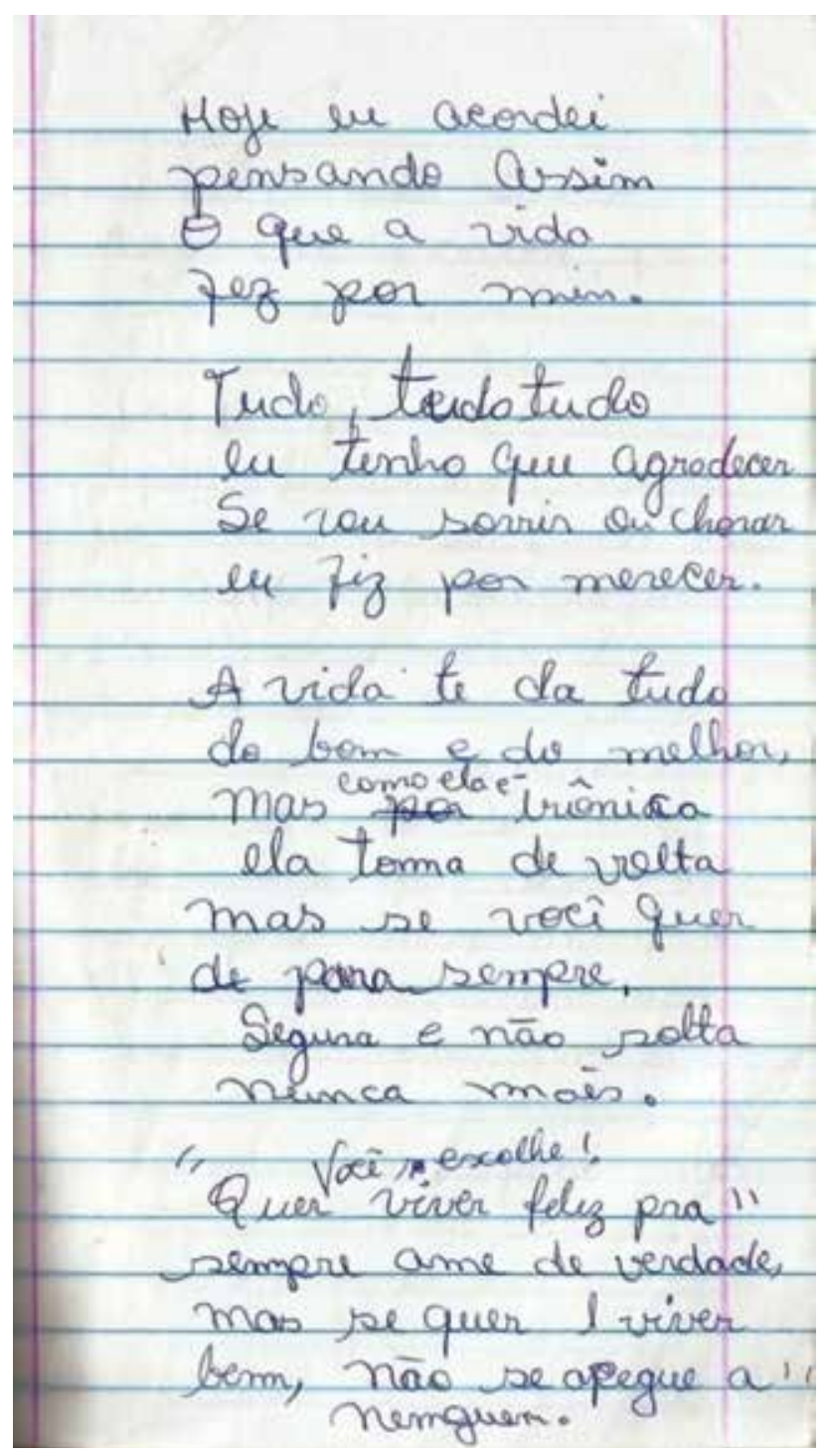

Fonte: banco de dados das autoras.

O primeiro poema, intitulado "Amanhecer", reflete sobre a importância de recomeçar. 0 segundo não possui título e reflete sobre o que o eu lírico havia conquistado e profere agradecimentos por essas conquistas. Em uma rápida análise, podemos constatar que a temática dos poemas é semelhante, pois, além de estar relacionada com a própria vida de $C$, esta faz uso de tal gênero para, por meio dele, refletir sobre sua própria condição humana. Vale lembrar que $C$ se encontrava em uma crise matrimonial e estava avaliando sua situação de vida, naquele momento.
Notamos que os poemas não têm relação com o conteúdo da narração diarística da data em que foram escritos. Esse indício fez com que encarássemos a ocorrência de poemas, no diário de C, também como um tipo de manifestação artística próprio da autora, além de seu uso como forma de reflexão. É importante ressaltar que, no dia a dia, $C$ não costuma compor poemas ou outros textos literários. Portanto, estamos compreendendo essas ocorrências artísticas como mais uma face de $\mathrm{C}$ para a produção diarística.

A ocorrência de poemas em diários não é rara, mas também não se pode afirmar que é tão comum. Alguns diaristas compõem poemas no clímax da narração, outros compõem poemas em outros ambientes, inclusive no diário, e há casos de diaristas que compõem toda a sua narração em forma de versos e essas escolhas estão relacionadas com o estilo do autor. Com relação aos diários que estamos investigando, de $\mathrm{C}$ e de $\mathrm{K}$, podemos dizer que a presença de poemas autorais, no decorrer do diário, caracteriza a escrita de C, do mesmo modo que a citação de textos literários conhecidos mundialmente caracteriza a escrita de K. Portanto, concluímos que a inserção de poemas autorais ou de textos de outros autores contribui para a construção memorial da personalidade do autor na confecção do diário.

Quanto aos aspectos estruturais, notamos que o diário de $C$ apresenta características bem tradicionais do gênero: folha de fundo branco, escrito apenas com caneta azul, não traz fotos nem muitas ilustrações, apresenta uma estrutura composicional também mais prototípica, como datação escrita à mão, vocativo, relato do dia e despedida, conforme ilustra a próxima figura (figura 14): 
Figura 14 - Aspectos estruturais do diário de C

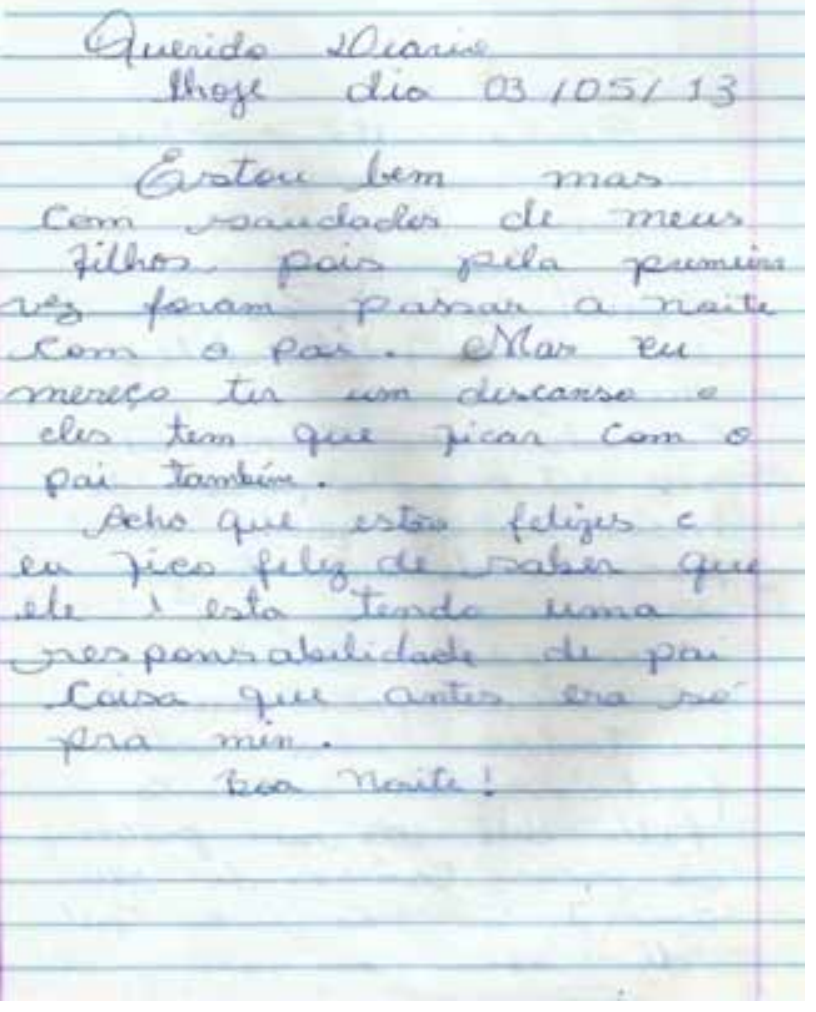

Fonte: banco de dados das autoras.

Lejeune (2014) postulou que a forma do diário é livre. Concordamos com o autor, pois acreditamos que o diarista é quem decide como configurá-lo. Apesar disso, concordamos também que o diário possui características formais que o singularizam diante dos demais gêneros da esfera autobiográfica, como a datação, o vocativo, a narração e a despedida. São por características como estas que sabemos que estamos diante de um diário e não de uma notícia, por exemplo. No entanto, por ser um gênero maleável, o estilo do autor encontra bastante espaço para se manifestar, mesmo em relação à estrutura do gênero, como nos mostrou $\mathrm{K}$, em várias ocorrências de sua escrita diarística. No caso de $\mathrm{C}$, notamos que ela adotou uma forma mais tradicional do gênero para produzir suas entradas.

Na figura 14, acima, assim como em outras que temos mostrado, observamos que $\mathrm{C}$ indicou a data no alto da página, optou por inse- rir, na maioria dos casos, o vocativo, relatou os fatos e, em seguida, despediu-se. Com relação ao vocativo, identificamos que não há uma forma predominante; pelo contrário, $C$ escolhe alguns interlocutores no decorrer da escrita: "querido diário", "Senhor", “Meu Deus". Além disso, destacamos que há momentos em que ele é dispensado, pois a autora inicia a narração sem a sua presença.

Do mesmo modo, não há uma despedida predominante: a autora escreve "Boa noite", "Até amanhã", "Por hoje é só", "Até, beijos" e, em se tratando de relatos com tendência religiosa, "Amém". Ao contrário dos vocativos, as despedidas aparecem em todas as narrações. Ao ser questionada sobre esse fato, $C$ nos devolveu outra pergunta: "Até eu me pergunto: despedir de quem?"

Além disso, observamos que a autora organizou seu diário de acordo com as entradas: cada entrada corresponde a uma página de, no máximo, frente e verso, ao contrário de $\mathrm{K}$, que introduz as narrativas a partir do princípio de economia de espaços, como ela mesma contou.

Em suma, a escrita de $C$ foi produzida em uma fase conflituosa: durante uma crise matrimonial. Ao acompanhar o diário, o leitor é convidado a viver com ela as angústias desse momento. O leitor vê em C uma mãe leal, mas se depara com uma mulher que não se sente realizada e que se encontra entre o dilema de ser ou não ser. Encontra-se com uma esposa frustrada, com um sujeito religioso, com uma poetisa, mas, sobretudo, lida com os lamentos e reflexões de atitudes passadas e presentes que perturbam a mente dessa mulher.

\section{Conclusão}

Como pudemos observar durante as análises, escrever textos íntimos é mais que uma decisão em registrar os fatos vivenciados por si mesmo; é, antes, uma forma de registrar a si mesmo, no sentido de que o escrevente re- 
gistra sua personalidade. No caso dos diários pessoais, por exemplo, temos uma forma de escrita bastante reveladora: escreve-se diariamente, ou em curtos intervalos, sobre o que o sujeito viveu e isso faz com que muitos aspectos individuais sejam eternizados: os gostos, os pensamentos, os receios, as alegrias e demais aspectos que constituem a personalidade do sujeito.

Em nossas análises, também descobrimos o estilo de cada uma em relação à produção de diários, o que nos revelou acerca das características do gênero em si. Na escrita de $\mathrm{K}$, identificamos maior recorrência de elementos subjetivos, de elementos de natureza semiótica diferente da escrita, como as fotografias, desenhos, recortes, entre outros, e descobrimos que esses recursos atuaram, sobretudo no primeiro diário, em favor da imagem romântica que K evidenciou de si mesma. Quanto aos aspectos estruturais, vimos que $K$ segue uma estrutura composicional bastante singular em sua composição escrita. Quanto à datação, por exemplo, indica apenas a data do ano ou o dia da semana correspondente à entrada e, imediatamente, reproduz a narrativa. Observamos, ainda, que a organização das entradas se dá por meio de um princípio de economia das páginas, de modo que, em uma única página pode haver duas ou mais entradas.

\section{Referências}

BAKHTIN, M. Os gêneros do discurso. In:

Estética da criação verbal. Tradução de Paulo Bezerra. São Paulo: Martins Fontes, 1997. p. 261-306.

LEJEUNE, P. Les journaux spirituals en France du XVIe au XVIIe siècle. Article publié dans Les Problématiques de l'autobiographie, no 33 de Littéralees. (Université Paris $X$ - Nanterre), 2004, p. 63-85.
Já na produção de C, não há nenhum elemento ilustrativo e ela utilizou uma estrutura mais padronizada do gênero para confeccionar seu diário. Na maioria das vezes, temos: a data no alto da página, o vocativo, a narração e a despedida. No entanto, houve variações estilísticas na maneira de inserir essa estrutura, como nos seguintes exemplos: a) o vocativo foi escrito de diferentes maneiras: querido diário, diarinho, Deus, Meu Deus, Senhor, Meu Senhor; b) a despedida também foi feita de diversas formas: boa noite, até amanhã, beijos, amém; c) até a maneira de configurar as narrativas do dia sofreu mudanças: reprodução dos fatos vivenciados naquele dia, reflexão sobre algum fato, oração, prece, inserção de poema. Essas variações entre os elementos tradicionais do gênero caracterizam o estilo de $C$.

Ainda que $\mathrm{K}$ tenha visivelmente um estilo mais individual e $C$ tenha um estilo mais padronizado, nos dois casos observamos a subjetividade de cada autora, ou seja, o estilo de cada uma. $K$ tende para uma escrita com muitos recursos visuais e $C$ para uma escrita respaldada nas palavras e na forma do gênero. Mesmo estas formas permitem muitas inovações, como $\mathrm{C}$ nos mostrou com as diferentes maneiras de escrever seus vocativos e despedidas.

O pacto autobiográfico: de Rousseau à Internet. Organização de Jovita Maria Gerheim Noronha; tradução de Jovita Maria Gerheim Noronha, Maria Inês Coimbra Guedes. 2 ed. Belo Horizonte: Editora UFMG, 2014.

MARCUSCHI, L. A. Gêneros Textuais: definição e funcionalidade. In: DIONISIO, A. P.; MACHADO, A. R.; BE- 
ZERRA, M. A. (Orgs.). Gêneros textuais e ensino. Rio de Janeiro: Lucerna, 2003. p. 19-36.

POSSENTI, S. Enunciação, autoria e estilo. Revista

da FAEEBA, Salvador, n. 15, p. 15-21, jan./jun., 2001.
RIBEIRO, P. B. Funcionamento do gênero do discurso.

Bakhtiniana, São Paulo, v. 1, n. 3, p. 54-67, 1o sem. 2010.

Recebido em: 20.04.2016

Aprovado em: 15.07 .2016

Jocelma Boto Silva é mestre em Linguística, pela Universidade Estadual do Sudoeste da Bahia (2016). Vice-diretora de ensino na rede pública em Piatã-BA. Tem experiência na área de Linguística Textual, com ênfase nos estudos sobre os gêneros discursivos, atuando principalmente nos estudos sobre os gêneros autobiográficos. E-mail: jocelmaboto@ gmail.com

Rua Isaias Matos, S/ N, Bairro Tangará. Piatã, Bahia. CEP: 46765-000

Márcia Helena de Melo Pereira é doutora em Linguística Aplicada, pela Universidade Estadual de Campinas (2005), onde também realizou o curso de mestrado em Linguística Aplicada. Professora adjunta do Departamento de Estudos Linguísticos e Literários da Universidade Estadual do Sudoeste da Bahia (DELL) e também docente permanente do Programa de Pós-Graduação em Linguística (PPGLin-UESB). E-mail: marciahelenad@yahoo.com.br

Rua Rio de Conta, 945, Condomínio Jardins Residence, casa 33, Bairro Candeias, Vitória da Conquista-BA, CEP: 45029-094 